\title{
Kelayakan Multimedia Interaktif Berbasis Scientific Approach Pada Pembelajaran IPA
}

\author{
Vicka Puspasari $^{1}$, Syafrimen Syafril ${ }^{1}$, Supriyadi Supriyadi ${ }^{1}$, Agus Pahrudin $^{1}, \operatorname{Titik}_{\text {Rahayu }^{2}}$ \\ 11vickapuspasari@gmail.com, ${ }^{1}$ syafrimen@radenintan.ac.id, ${ }^{1}$ supriadi@radenintan.ac.id, \\ 1'aguspahrudin@radenintan.ac.id, ${ }^{2}$ p91583@siswa.ukm.edu.my \\ ${ }^{1}$ Universitas Islam Negeri Raden Intan Lampung, Jl. Letkol H. Endro Suratmin, Sukarame, \\ Bandar Lampung, Indonesia \\ ${ }^{2}$ Fakulty of Education, Universiti Kebangsaan Malaysia, 43600 UKM Bangi, Selangor, Malaysia \\ *Corresponding author: syafrimen@radenintan.ac.id
}

Tel.: +6281374576227

\begin{abstract}
ABSTRAK
Multimedia interaktif merupakan salah satu media pembelajaran yang dapat memudahkan siswa dalam memahami pelajaran. Penelitian ini bertujuan untuk menilai kelayakkan multimedia interaktif berbasis scientific approach pada mata pelajaran Ilmu Pengetahuan Alam (IPA) untuk siswa sekolah menengah. Research and Development digunakan sebagai metode penelitian. Tiga orang subjek dilibatkan sebagai validator untuk menilai kelayakkan materi, bahasa dan media. Empat puluh delapan orang siswa dan 1 orang guru IPA memberikan respon terhadap multimedia interaktif yang dibangunkan. Penilaian ahli terhadap kelayakkan multimedia interaktif dikumpulkan menggunakan lembar penilaian, sedangkan respon siswa dan guru menggunakan angket. Data dianalisis menggunakan statistik deskriptif berbantukan Statistical Package for The Social Sciences (SPSS windows 22.0). Hasil penelitian menunjukkan bahwa penilaian ahli materi sangat layak (89\%), ahli bahasa layak (75\%) dan ahli media sangat layak $(86 \%)$, sedangkan respon siswa dan guru sangat menarik (siswa $=85 \%$ dan guru=92\%). Ini menunjukkan bahwa multimedia interaktif bebasis scientific approach sangat layak dan dapat dijadikan sebagai salah satu alternatif pemilihan media dalam pembelajaran IPA di sekolah menengah.
\end{abstract}

Kata kunci: multimedia interaktif, scientific approach, pembelajaran IPA 


\section{Pendahuluan}

Pembelajaran IPA bertujuan memberikan nilai positif terhadap siswa, antar lain: (i) kesadaran keindahan dan keteraturan alam, (ii) mengetahui konsep, prinsip, serta keterkaitannya, (iii) terampil dan mampu memecahkan masalah, (iv) memiliki sikap ilmiah, (v) mampu berpikir analisis, (vi) apresiatif terhadap sains (Trianto, 2014). Pembelajaran menggunakan scientific approach dapat digunakan untuk memenuhi tujuan pembalajaran IPA karena melibatkan kegiatan ilmiah seperti mengamati, menanya, mengumpulkan informasi, mengasosiasi dan mengomunikasikan (Sani, 2017; Ratnaningsih, Hidayat, \& Akbar, 2016; Daryanto, 2014). Multimedia interaktif merupakan gabungan dari tiga elemen yaitu gambar, suara dan teks yang dapat digunakan untuk menyampaikan pesan dan dapat dikontrol langsung oleh pengguna (Darmawan, 2012; A. H. Sutopo, 2013; Vaughan, 2011). Penggunaan multimedia interaktif oleh guru dapat meningkatan motivasi, pemahaman, dan konsentrasi siswa untuk mencapai tujuan pembelajaran (Vebrianto \& Osman, 2011; Alfatah, Tjandrakirana, \& Prastiwi, 2015; Lee \& Osman, 2012).

Beberapa penelitian menunjukkan masih banyak siswa kesulitan dalam memahami pelajaran IPA (Alfatah, Tjandrakirana, \& Prastiwi, 2015; Otzman et al., 2008; Agung \& Schwartz, 2007). Banyak konsep dan subjek yang tidak dapat dipahami oleh siswa secara komprehensif (Kozma \& Russell, 1997), sehingga kebanyakkan siswa beranggapan bahwa mata pelajaran IPA sulit (Pekdag, 2010). Proses pembelajaran IPA yang terlalu abstrak dan konseptual menyebabkan pembelajaran menjadi sulit, karena sememangnya cara guru dalam menyampaikan materi sangat berpengaruh terhadap siswa dalam memahami materi (Çimer, 2012). Pembejaran IPA mayoritasnya banyak siswa yang hanya sekedar menghapal konsep tanpa memahami konsep tersebut sepenuhnya (Niaz \& Rodriguez, 2000). Penggunaan media gambar dan torso dalam pula masih digunakan secara terpisah oleh guru dalam pembelajaran IPA (Isnaini, Wigati, \& Oktari, 2016). Masih banyak guru menggunakan cara menghafal fakta, sehingga keterlibatan siswa dalam pembelajaran masih sangat terbatas. Seharusnya guru memiliki sifat empati yang tinggi terhadap siswa (Syafrimen, Ishak, \& Erlina, 2017) dengan cara memberikan proses pembelajaran yang sangat memudahkan siswa, sehingga tujuan pembelajaran dapat dicapai dengan baik. Justeru, penggunaan multimedia interaktif oleh guru dapat memudahkan siswa, meningkatkan motivasi, pemahaman, dan konsentrasi siswa dalam pembelajaran (Alfatah et al., 2015; Vebrianto \& Osman, 2011).

Penelitian tentang multimedia interaktif dengan pendekatan, metode dan materi yang berbeda sudah dilakukan oleh penelitian-penelitian sebelumnya, diantaranya berbasis inkuiri (Abdullah \& Shariff, 2008), berbasis nilai (Komalasari \& Saripudin, 2017), materi keseimbangan kimia (Ollino, Aldoney, Dominguez, \& Merino, 2018), sistem periodik (Sari, Aryana, Subarkah, \& Ramdhani, 2018), berpikir kritis (Yohandri; Djamas; Tinedi, 2018), cancer cell Biology (Bockholt, West, \& Bollenbacher, 2002). Bagaimanapun penelitian tentang 
multimedia interaktif berbasis scientific approach masih sangat sedikit dilakukan. Penelitian sebelumnya mengaitkan multimedia interaktif berbasis scientific approach pada mata pelajaran kewarganegaraan (Rachmadtullah, MS, \& Sumantri, 2018). Sedangkan kebutuhan multimedia interaktif dalam pembelajaran IPA dapat mempermudah proses pembelajaran (Khan \& Masood, 2015; Leow \& Neo, 2014). Justru penelitian ini bertujuan untuk menilai kelayakkan multimedia interaktif berbasis scientific approach pada pembelajaran IPA tersebut.

\section{Metode Penelitian}

Penelitian dijalankan menggunakan Research and Development. Pemilihan metode tersebut sangat sesuai untuk mencapai tujuan penelitian ini. Lima puluh dua orang dilibatkan dalam penelitian ini sebagai sumber data. Tiga orang ahli sebagai penilai kesesuaian materi, bahasa dan multimedia. Satu orang guru sebagai penilai multimedia yang dikembangkan dari sisi kelayakan dalam proses pembelajaran IPA. Empat puluh delapan orang siswa (6 orang uji 1 lawan 1, 12 orang ujian kelompok kecil, dan 30 orang uji kelompok besar). Data penilaian ahli dikumpulkan menggunakan lembar penilaian, sedangkan data guru dan siswa dikumpulkan melalui angket. Selnjutnya data dianalisis menggunakan statistik deskriptif berbantukan Statistical Package for The Social Sciences (SPSS windows 22.0).

\section{Hasil Penelitian}

Multimedia interaktif disusun berdasarkan KI dan KD kurikulum 2013. Desain multimedia interaktif terdiri dari halaman depan, cara penggunaan, menu utama, tujuan pembelajaran, KI dan KD, langkah-langkah pembelajaran saintifik, kumpulan materi sistem pencernaan pada manusia dan latihan soal. Berikut dipaparkan hasil penilaian ahli, respons guru dan siswa.

Tabel 3.1. Penilaian para ahli, respon guru dan siswa

\begin{tabular}{lcc}
\multicolumn{1}{c}{ Respon } & Persentase & Keterangan \\
\hline Ahli materi & & Sangat layak \\
Ahli bahasa & $89.00 \%$ & Layak \\
Ahli media & $80.00 \%$ & Sangat layak \\
Guru & $92.00 \%$ & Sangat menarik \\
Siswa & $85.00 \%$ & Sangat menarik \\
\hline Nilai Rata-rata & $84.40 \%$ & Sangat layak \\
\hline
\end{tabular}

Penilaian awal yang diberikan oleh ahli materi yaitu sebesar 70\% dengan kategori layak. Pada validasi tahap kedua ini, media mendapatkan kategori sangat layak dengan persentase $89 \%$. Ahli bahasa memberikan penilaian 75\% dengan kategori layak. Saran yang diberikan adalah bahasa yang digunakan disesuaikan dengan murid SMP. Validasi tahap pertama oleh ahli media diberikan nilai sebesar $81 \%$, dan setelah dilakukan perbaikan pada tahap kedua diberikan nilai 
86\%. Guru memberikan penilaian 92\% (sangat baik). Demikian juga halnya dengan siswa juga memberikan peilaian $85 \%$ (sangat baik) terhadap multimedia interaktif yang dibangunkan.

\section{Pembahasan}

Multimedia interaktif layak digunakan sebagai media pembelajaran dengan sedikit perbaikan, baik pada materi maupun pada tampilannya, sejalan dengan penelitian terdahulu (Rachmadtullah et al., 2018; Ratnaningsih et al., 2016; Arda, Saehana, \& Darsikin, 2015; Abtahi, 2012) yang menyatakan bahwa diperlukan sedikit perbaikan pada multimedia interaktif apabila mendapatkan penilaian layak dalam proses pembangunanya. Penilaian sedemikian menunjukkan bahwa multimedia interaktif yang dibangunkan layak untuk diuji coba lapangan dan layak digunakan dalam pembelajaran. Hasil penelitian ini sejalan dengan penelitian sebelumnya yang juga melakukan proses yang lebih kurang sama dalam membangunkan media pembelajaran IPA berupa Lembar Kerja Siswa (Pawana, Suaharsono, \& Kirna, 2014; Rahayu, Syafril, \& Wati, 2016).

Video dan gambar yang tersedia pada multimedia interaktif sangat membantu dalam memahami gambaran nyata pada pembelajaran IPA, contohnya dalam pembelajaran proses pencernaan manusia. Hal tersebut dinyatakan oleh penelitian terdahulu bahwa lebih dari 75\% video dapat membantu siswa dalam memahami materi, dan memberikan informasi yang sangat jelas dalam pembelajaran yang dijalankan (Leow \& Neo, 2014). Penilaian ahli media menyatakan bahwa multimedia interaktif yang digunakan mendapat nilai yang tinggi dalam (i) tampilan yang menarik, (ii) keserasian warna dan huruf yang baik, (iii) gambar, video dan audio yang jelas, (iv) respon yang diberikan media tepat dan cepat, dan (v) mudah dalam pengoperasian. Hal tersebut sejalan dengan penelitian yang menyatakan bahwa standar pembuatan desain multimedia dalam pendidikan harus memiliki kriteria tersebut (Mohammad \& Ahmad, 2015).

Ahli materi menyatakan bahwa materi yang disajikan sesuai dengan KI dan KD, indikator, dan tujuan pembelajaran. Hal tersebut sejalan dengan hasil penelitian sebelumnya mengenai penyajian materi yang sesuai dengan tujuan pembelajaran, berurutan, dan sesuai dengan konsep (Alfatah et al., 2015; Kwanjai Deejring, 2014). Berkaitan dengan kelayakkan multimedia interaktif, banyak penelitian terdahulu mendapati bahwa multimedia interaktif dapat meningkatkan pemahana siswa (Vebrianto \& Osman, 2011; Alfatah, Tjandrakirana, \& Prastiwi, 2015; Lee \& Osman, 2012), hal tersebut dikarenakan multimedia yang dibuat dianggap menarik bagi siswa sehingga meningkatkan keingintahuan dan motivasi belajar siswa. Hal tersebut selaras dengan hasil penelitian ini yang menyebutkan bahwa multimedia interaktif yang dibuat mendapat respon sangat menarik bagi siswa. 


\section{Kesimpulan}

Penelitian ini memberikan kontribusi terhadap ide-ide pengembangan media pembelajaran menggunakan multimedia interaktif. Pengembangan multimedia interaktif berbasis scientific approach sangat memungkinkan rasional dapat membantu proses pembelajaran IPA di sekolah. Tuntutan pembelajaran IPA sesungguhnya adalah proses pembelajaran harus dilakukan secara real bukanya abstrak. Untuk menjadikan proses pembelajaran tersebut seolah-olah menjadi real, maka penggunaan multimedia interaktif salah satu solusinya. Penelitian ini membuktikan bahwa penggunaan multimedia interaktif membuat proses pembelajaran menjadi lebih menarik dan bermakna, seperti terlihat melalui respons guru dan siswa dalam penelitian ini. Apakah yang menjadikan proses pembelajaran tersebut menarik dan bermakna? Jawabanya adalah adanya gabungan video dan penjelasan dalam bentuk audio, serta gambar dengan menggunakan langkah-langkah pembelajaran scientific.

\section{Acknowledgement}

Terimakasih setinggi-tingginya disampaikan kepada bapak Syafrimen, M.Ed, Ph.D yang membimbing sangat luar biasa, sekaligus berkolaborasi sepenuhnya untuk menyiapkan artikel ini sehingga menjadi sebuah artikel ilmiyah yang layak dijadikan sebagai salah rujukan, khususnya dalam pembelajaran IPA. Terima kasih tidak terhingga juga kepada bapak Supriyadi, M.Pd, dan Bapak Dr. Agus Pahrudin, M. Pd yang juga memberikan sumbangan sangat luar biasa dalam penyelasaian artikel ini. Semoga kolaborasi ilmiyah seperti ini selalu terjaga untuk pengembangan ilmu pengetahuan secara berkesinambungan.

\section{Rujukan}

A. H. Sutopo. (2013). Multimedia Interaktif dengan Flash. Yogyakarta: Graha Imu.

Abdullah, S., \& Shariff, A. (2008). The effects of inquiry-based computer simulation with cooperative learning on scientific thinking and conceptual understanding of gas laws. Eurasia Journal of Mathematics, Science and Technology Education, 4(4), 387-398.

Abtahi, M. S. (2012). Interactive Multimedia Learning Object (IMLO) for Dyslexic Children. Procedia - Social and Behavioral Sciences, 47.

Agung, S., \& Schwartz, M. S. (2007). Students' Understanding of Conservation of Matter, Stoichiometry and Balancing Equations in Indonesia. International Journal of Science Education, 29(13).

Alfatah, A., Tjandrakirana, \& Prastiwi, M. S. (2015). BioEdu BioEdu. BioEdu, 4(1), 821.

Arda, A., Saehana, S., \& Darsikin, D. (2015). Pengembangan Media Pembelajaran Interaktif Berbasis Komputer Untuk Siswa Smp Kelas VIII. E-Jurnal Mitra Sains, 3(1), 69-77.

Bockholt, S. M., West, J. P., \& Bollenbacher, W. E. (2002). Cancer Biology Cell: A Studentcentered Instructional Module Exploring the Use of Multimedia to Enrich Interactive, 
Contructivist Learning of Science. Electronic Resources.

Çimer, A. (2012). What makes biology learning difficult and effective: S tudents' views. Educational Research and Reviews, 7(3).

Daryanto. (2014). Pendekatan Pembelajaran Saintifik Kurikulum 2013. Yogyakarta: Gava media.

Deni Darmawan. (2012). Teknologi Pembelajaran (p. 31). Bandung: Remaja Rosdakarya.

Isnaini, M., Wigati, I., \& Oktari, R. (2016). Pengaruh Penggunaan Media Pembelajaran Torso Pencernaan Pada Manusia Di Smp Negeri 19 Palembang. Jurnal Biota, l(1).

Khan, F. M. A., \& Masood, M. (2015). The Effectiveness of an Interactive Multimedia Courseware with Cooperative Mastery Approach in Enhancing Higher Order Thinking Skills in Learning Cellular Respiration. Procedia - Social and Behavioral Sciences, 176, 977-984.

Komalasari, K., \& Saripudin, D. (2017). Value-based interactive multimedia development through integrated practice for the formation of students' character. Turkish Online Journal of Educational Technology, 16(4), 179-186.

Kozma, R. B., \& Russell, J. (1997). Multimedia and understanding: Expert and novice responses to different representations of chemical phenomena. Journal of Research in Science Teaching, 34(9).

Kwanjai Deejring. (2014). The design of web-based learning model using collaborative learning techniques and a scaffolding system to enhance learners ' competency in higher education. Procedia - Social and Behavioral Sciences, 116, 437.

Lee, T. T., \& Osman, K. (2012). Interactive Multimedia Module in the Learning of Electrochemistry: Effects on Students' Understanding and Motivation. Procedia - Social and Behavioral Sciences, 46.

Leow, F.-T., \& Neo, M. (2014). INTERACTIVE MULTIMEDIA LEARNING: INNOVATING CLASSROOM EDUCATION IN A MALAYSIAN UNIVERSITY. PTOJET: The Turkish Online Journal of Educational Technology, 13(2), 99-110.

Mohammad, O., \& Ahmad, A. (2015). Standards of Multimedia Graphic Design in Education, $6(17)$.

Niaz, M., \& Rodriguez, M. A. (2000). Teaching Chemistry as Rhetoric of Conclusions or Heuristic Principles- a History and Philosophy of Science Persepektive. Chemistry Education, 1(3).

Ollino M, J, A., A, D., \& Merino C. (2018). A new multimedia application for teaching and learning chemical equilibrium. Chemistry Education Research and Practice, 19, 364.

Otzman, J., Treagust, D. F., \& Chandrasegaran, A. L. (2008). An Investigation into the Relationship between Students' Conceptions of the Particulate Nature of Matter and their Understanding of Chemical Bonding. International Journal of Science Education, 30(11).

Pawana, M. G., Suaharsono, N., \& Kirna, I. M. (2014). PENGEMBANGAN MULTIMEDIA 
INTERAKTIF BERBASIS PROYEK DENGAN MODEL ADDIE PADA MATERI PEMROGRAMAN WEB SISWA KELAS X SEMESTER GENAP. E-Journal Program Pascasarjana Universitas Pendidikan Ganesha, 4, 7.

Pekdag, B. (2010). Alternative Methods in Learning Chemistry: Learning with Animation, Simulation, Vidio, and Multimedia. Journal of Turkish Science Education, 7(2).

Rachmadtullah, R., MS, Z., \& Sumantri, M. S. (2018). Interactive Multimedia Development Based on Scientific Approach on Civic Education Subjects in Elementary School. Interciencia, 47(7), 13-21.

Rahayu, T., Syafril, S., \& Wati, W. (2016). Lembar Kerja Siswa (LKS) IPA Terpadu dalam Pembelajaran Fisika. ICIHE.

Ratnaningsih, N., Hidayat, E. D. I., \& Akbar, R. R. E. L. (2016). SCIENTIFIC APPROACHBASED OF INTERACTIVE LEARNING MEDIA TO IMPROVE MATHEMATICAL THINKING SKILL AND SELF-REGULATED LEARNING.

Sani, R. A. (2017). Pembelajaran Saintifik untuk Implementasi Kurikulum 2013 (p. 50). Jakarta: Bumi Aksara.

Sari, S., Aryana, D. M., Subarkah, C. Z., \& Ramdhani, M. A. (2018). Multimedia Based on Scientific Approach for Periodic System of Element. IOP Conference Series: Materials Science and Engineering, 288(1), 012137. https://doi.org/10.1088/1757-899X/288/1/012137

Syafrimen, Ishak, N. M., \& Erlina, N. (2017). Six Ways to Develop Empathy of Educators. Journal of Engineering and Applied Sciences, 12(7).

Trianto. (2014). Model Pembelajaran Terpadu (p. 143). Bandung: Rosdakarya.

Vaughan, T. (2011). Multimedia: Making It Work (Edisi ke-8). McGraw-Hill.

Vebrianto, R., \& Osman, K. (2011). The effect of multiple media instruction in improving students' science process skill and achievement. Procedia - Social and Behavioral Sciences, 15,347 .

Yohandri; Djusmaini Djamas; Vonny Tinedi. (2018). Development of Interactive Multimedia Learning Materials for Improving Critical Thinking Skills. International Journal of Information and Communication Technology Education, 14, 66-84. 